Abstracta Iranica Abstracta Iranica

Revue bibliographique pour le domaine irano-aryen

Volume 22 | 2001

Comptes rendus des publications de 1999

Orta Asya türk cümhuriyetleri. Istanbul, Alfa Yayınları, 1998, 312 p. [Les Républiques türkes d'Asie centrale]

Bayram Balci

(2) OpenEdition

Journals

Édition électronique

URL : http://journals.openedition.org/abstractairanica/37283

DOI : $10.4000 /$ abstractairanica.37283

ISSN : 1961-960X

Éditeur :

CNRS (UMR 7528 Mondes iraniens et indiens), Éditions de l'IFRI

Édition imprimée

Date de publication : 15 mai 2001

ISSN : 0240-8910

Référence électronique

Bayram Balci, «Orta Asya türk cümhuriyetleri. Istanbul, Alfa Yayınları, 1998, 312 p. [Les Républiques türkes d'Asie centrale] », Abstracta Iranica [En ligne], Volume 22 | 2001, document 619, mis en ligne le 17 février 2010, consulté le 13 octobre 2020. URL : http://journals.openedition.org/abstractairanica/ 37283 ; DOI : https://doi.org/10.4000/abstractairanica.37283

Ce document a été généré automatiquement le 13 octobre 2020.

Tous droits réservés 


\title{
Orta Asya türk cümhuriyetleri. Istanbul, Alfa Yayınları, 1998, 312 p. [Les Républiques türkes d'Asie centrale]
}

\author{
Bayram Balci
}

Cet ouvrage collectif offre sur les États türkophones d'Asie centrale des contributions de qualité très variable. L'article de Gökhan Bacik sur les questions d'identité collective dans les républiques türkophones est sans doute le meilleur de l'ouvrage. L'A. y aborde avec subtilité la recherche actuelle d'un modèle de développement économique et politique, marquée selon Bacik par une hésitation entre le renforcement de l'ethnie dominante et celui de la dimension islamique dans la construction des nouvelles identités nationales. Fahrettin Canbar s'étend ensuite sur les facteurs jouant en faveur d'une démocratisation de ces États, mais il s'attarde inutilement sur le "tribalisme » supposé des sociétés centrasiatiques, pour se contenter finalement d'une synthèse des articles parus sur les mêmes questions dans le Central Asian Survey entre 1994 et 1997. Enfin deux articles d'Ahmet Kuru offrent un condensé de ce qui se fait de pire en Turquie aujourd'hui : le premier survole les relations entre la Turquie et l'Asie centrale au cours des neuf derniers siècles; le second insiste sur la nécessaire intégration politique entre la Turquie et les « républiques » türkophones d'Asie centrale. Coupé des réalités politiques et sociales du terrain turc et centrasiatique, l'A. construit des schémas théoriques peu intelligibles, qui achèvent de nuire à la crédibilité du présent recueil. 
INDEX

Thèmes : 13.3. Asie centrale

\section{AUTEURS}

BAYRAM BALCI

Paris 